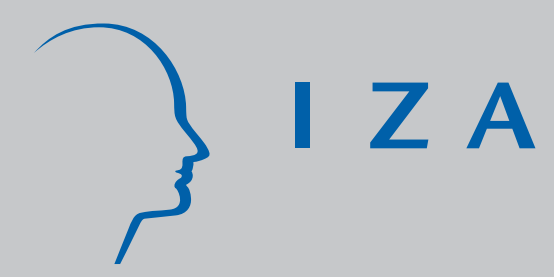

IZADP No. 3652

The In-Hospital Mortality Rates of Slaves and Freemen: Evidence from Touro Infirmary, New Orleans, Louisiana, 1855-1860

J onathan Pritchett Myeong-Su Yun

August 2008 


\title{
The In-Hospital Mortality Rates of Slaves and Freemen: Evidence from Touro Infirmary, \\ New Orleans, Louisiana, 1855-1860
}

\author{
Jonathan Pritchett \\ Tulane University \\ Myeong-Su Yun \\ Tulane University and IZA
}

Discussion Paper No. 3652

August 2008

IZA

P.O. Box 7240

53072 Bonn

Germany

Phone: +49-228-3894-0

Fax: +49-228-3894-180

E-mail: iza@iza.org

\begin{abstract}
Any opinions expressed here are those of the author(s) and not those of IZA. Research published in this series may include views on policy, but the institute itself takes no institutional policy positions.

The Institute for the Study of Labor (IZA) in Bonn is a local and virtual international research center and a place of communication between science, politics and business. IZA is an independent nonprofit organization supported by Deutsche Post World Net. The center is associated with the University of Bonn and offers a stimulating research environment through its international network, workshops and conferences, data service, project support, research visits and doctoral program. IZA engages in (i) original and internationally competitive research in all fields of labor economics, (ii) development of policy concepts, and (iii) dissemination of research results and concepts to the interested public.
\end{abstract}

IZA Discussion Papers often represent preliminary work and are circulated to encourage discussion. Citation of such a paper should account for its provisional character. A revised version may be available directly from the author. 
IZA Discussion Paper No. 3652

August 2008

\begin{abstract}
The In-Hospital Mortality Rates of Slaves and Freemen: Evidence from Touro Infirmary, New Orleans, Louisiana, 1855-1860*

Using a rich sample of admission records from New Orleans Touro Infirmary, we examine the in-hospital mortality risk of free and enslaved patients. Despite a higher mortality rate in the general population, slaves were significantly less likely to die in the hospital than the whites. We analyze the determinants of in-hospital mortality at Touro using Oaxaca-type decomposition to aggregate our regression results. After controlling for differences in characteristics and maladies, we find that much of the mortality gap remains unexplained. In conclusion, we propose an alternative explanation for the mortality gap based on the selective hospital admission of slaves.
\end{abstract}

JEL Classification: N31, J15, I10

Keywords: $\quad$ slavery, hospital, Oaxaca-type decomposition, New Orleans, Touro

Corresponding author:

Jonathan B. Pritchett

Department of Economics

Tulane University

Tilton Hall, 309C

New Orleans, LA 70118

USA

E-mail: jprit@tulane.edu

\footnotetext{
* We thank the editor, an anonymous referee, and members of the Tulane seminar series for their helpful comments and suggestions. Data used in this study were transcribed in machine-readable form by the archivists at Touro hospital. We thank Ms. Catherine Kahn and the staff at Touro Hospital archives for making these data available.
} 


\section{Introduction}

Prior to the Civil War, many urban hospitals in the southern United States provided medical care for slaves. ${ }^{1}$ In addition to the public hospital, at least six private hospitals treated slaves in New Orleans, the most populous city in the antebellum South. These private hospitals charged owners for the medical treatment of their slaves and advertised in local newspapers and city directories in search of clients. For some of these hospitals, slaves represented the majority of their patients and a major source of revenue. In addition, the large number of hospitals which treated slaves is indirect evidence of the owners' demand for hospital care. $^{2}$

The quality or effectiveness of the hospital care received by slaves is largely unknown. Most private hospitals offered their white patients a variety of accommodations and prices. Slaves were typically segregated from whites, housed in less desirable locations, and their owners charged lower fees. Surprisingly, the slaves admitted to Touro Infirmary, a small private hospital operating during the 1850s, had lower mortality rates than the whites. In this paper, we use probit analysis to examine the determinants of in-hospital mortality at Touro. The disparities in mortality rates between whites and slaves are examined using Oaxaca-type decomposition based on the probit estimates.

\footnotetext{
${ }^{1}$ Slaves received hospital care in Augusta (Phillips 1918, p. 404), Richmond, Norfolk (Savitt 1978, pp. $192-$ 194), Charleston, Montgomery (Goodson 2003, p. 228), Mobile (Wade 1964, p. 140), Atlanta (Washington 2006, p. 107), Savannah, Natchez, and Springfield, Louisiana (Postell 1951, p. 139).

${ }^{2}$ During the 1850 s, slaves received treatment in New Orleans at Charity Hospital (a public hospital), Circus Street Infirmary, Dr. Beard's Eye Infirmary, Hotel Dieu, Stone's Infirmary (formerly the Mason de Santé), Touro Infirmary, and Luzenberg's Infirmary (Postell 1951, p. 138). Bozeman's Hospital specialized in the care and treatment of women, including slaves. For the year 1860, 428 of the 692 patients admitted to Stone's Infirmary were blacks -- most of whom were slaves (Richardson 1861, p. 202). After the Civil War, the Circus Street Infirmary, Bozeman's Hospital, and Stone's Infirmary closed. Postell (1951, p. 66) finds that after the war, "the altered state of the Negro had materially affected the income of every physician... [A] slave was always good for his bill, since it was the owner who was responsible."
} 
Tropical diseases and the seasonality of admissions explain a substantial portion of the difference in mortality rates between whites and slaves. Nevertheless, after controlling for these variables, we find a substantial mortality gap. Slaves had lower baseline mortality rates than whites which suggests that that the slaves were in better health at the time of hospital admission. Alternative explanations for the mortality gap, including selective admission decisions by slave owners, are discussed in the conclusion.

Although hospital records contain unique and valuable information about the antebellum health care system, economic historians rarely use them. Goldin and Margo (1989) used hospital records to estimate the birth weights and infant mortality of children born in Philadelphia's Almshouse Hospital, and Tunalı and Pritchett (1997) used admission records from New Orleans's Charity Hospital to estimate mortality rates during the yellow fever epidemic of 1853. Rarer still is the use of hospital records of slaves. Bankole (1998; 2001) used Touro hospital records to describe the experience of female slaves in antebellum hospitals whereas Lander and Pritchett (2008) used these records to describe the characteristics of slaves admitted to the hospital. Neither of these studies addressed the inhospital mortality experience of slaves.

\section{Data description}

Established in 1852, Touro Infirmary was named for philanthropist Judah Touro who provided funding for the hospital as part of his estate. The original hospital was an old plantation house located on the corner of Gaienne and New Levee (later renamed Peters) streets, near the wharves and levees of the Mississippi river. An early advertisement for the hospital describes it as "one of the best ventilated and arranged Institutions in the Southern 
Country" (Cohen, 1855, p. 229) and a local newspaper praised the "commodious arrangements for the comfort of the patients" (New Orleans Bee, August 18, 1852). In describing the hospital's location, Dr. Loeber, one of the house physicians, was less complimentary. In 1869, he wrote that the hospital was surrounded by "factories and boiler shops on one of the noisiest streets in the city" (Burnett 1979, p. 34). The hospital soon outgrew its quarters and in 1882 moved to its present location on Prytania and Delachaise streets where it operates today.

Approximately half of the 1,580 patients admitted to Touro Infirmary between January 1, 1855 and March 31, 1860 were slaves. ${ }^{3}$ Under a column entitled "occupation" found in the admissions book, 679 of these patients (or approximately 43 percent of the total) were explicitly recorded as slaves. Beginning in the year 1859, however, the occupations of some slaves were recorded rather than their enslaved status. Using the recorded occupations of patients to identify their status would result in the misclassification of these slaves. Fortunately, we have an alternative method for identifying these misclassified patients. Because the surnames of most slaves were not recorded in the admissions book, we classify those patients without recorded surnames as slaves (see Lander and Pritchett, 2008). Allowing for this reclassification increases the total number of enslaved patients to 831 , or approximately 52 percent of the sample.

Most private hospitals in New Orleans segregated their patients by both race and class. At Luzenberg's Infirmary, for example, the "better order of patients" paid three dollars a day for private rooms located on the hospital's first floor, with the "upmost care and

\footnotetext{
${ }^{3}$ Admission records include information on the name, age, and occupation of the patient, birth place, last place from, length of residence in New Orleans, dates of admission, discharge, or death, malady, responsible party, length of hospitalization, marital status, and rate per day. The hospital closed in 1860 with the departure of the resident physician.
} 
attention paid to all their wants and wishes." White patients paying one dollar a day were admitted to a second-story ward whereas the third-story attic was reserved for black patients (New Orleans Bee, September 4, 1835). A separate part of the Circus Street Hospital was appropriated for slaves, and was "furnished in the most comfortable manner" (Cohen, 1855). The Orleans Infirmary advertised available apartments "at a suitable distance from the main building, for the reception of Slaves" (New Orleans Advertiser, June 12, 1830). We suspect that Touro was similar to these other hospitals and segregated the patients. Because it was a small hospital with only twenty-four beds (Burnett 1979, p.2), slaves and freemen were probably treated in close proximity.

In his history of hospitals in the United States, Charles Rosenberg (1987) writes that early hospitals were seen as a last resort for the poor and homeless. Most contemporary hospitals were almshouses and did not charge fees although they sometimes required the recovered patients to help care for the sick. Even the private hospitals provided free care for most patients. ${ }^{4}$ In mid-nineteenth century America, "none but the truly indigent would voluntarily enter a hospital." Patients were "naturally ashamed" of their predicament, having been abandoned "by family, by employers, [and] even by [their church] congregations." Only "the destitute and friendless" would seek treatment in a hospital, which served as an asylum for the dependent and socially isolated members of society. Indeed, "no responsible master of a servant would allow even a hired member of his or her 'family' to be cared for by strangers" (Rosenberg 1987, p. 16, 21, 25, 116, 237).

Although Touro Infirmary was established as a charitable institution, most patients were charged for their medical care. Touro's board of directors contracted with Dr. Joseph

\footnotetext{
${ }^{4}$ For example, during the first century of its operation $(1752$ - 1854), the private Pennsylvania Hospital charged less than 30 percent of the patients for their board (calculated from Rosenberg 1987, p. 32).
} 
Bensadon to serve as resident physician and to provide everyday management of the hospital. As part of his contract, Bensadon was required to admit charity patients as designated by the members of the board (Burnett 1979, p. 2, 28). These charity patients comprised less than 25 percent of the white patients admitted to the hospital. Most whites were charged a daily rate of one to five dollars, depending on the level of service provided by the hospital. An expectation of payment was especially true for the slaves treated at Touro. Because slaves were valuable property, most slave owners were wealthy and financially capable of paying their hospital bills. With few exceptions, the owners of enslaved patients were charged a uniform rate of $\$ 1$ per day, in addition to any charges for surgical procedures. ${ }^{5}$ Although some white patients were admitted for free, almost all slave owners paid for the care of their slaves. As evident from the large number of slaves admitted to Touro and other private hospitals, New Orleans masters were more than willing to let strangers care for their ailing servants.

Almshouse hospitals served a dual purpose of providing care for the sick and shelter for the homeless. Many of the patients suffered from chronic illnesses and remained hospitalized for weeks or months. Some of their hospital stays were quite lengthy. At the Philadelphia Almshouse in 1807, for example, the average length of stay for patients in general wards was one year and three to five years for patients in the incurable wards. Indigence rather illness seemed to dictate the length of the hospital stay. According to Rosenberg (1987, p. 27), most patients were "simply not that sick." The health of these patients may account for their relatively low mortality rates. Indeed, Rosenberg (1987, p. 116) finds that only the worse hospitals at the worse times had death rates exceeding 10

\footnotetext{
${ }^{5}$ Touro Infirmary advertised daily rates of $\$ 1$ for slaves (Cohen, 1855, p. 229). For slaves with recorded rates, 96 percent were charged $\$ 1$ per day and only one slave was admitted for free. The records of free persons of color are notable absent in the admission books.
} 
percent. Rather than being discharged, chronically ill patients remained in these hospital because they had nowhere else to go.

In contrast to the almshouse hospitals, Touro Infirmary resembled an acute-care facility. The average length of stay was less than 14 days and the median was only nine days. For patients admitted 1855-1860, the longest stay at Touro was only five months. Presumably because they were charged for their board, patients had an incentive to shorten their hospital stays. Unlike the almshouse hospitals, most patients came to Touro because they were deathly ill and needed hospital care. Similar to the other contemporary New Orleans hospitals, the death rate at Touro was extremely high, averaging 15 percent for the years of our study. ${ }^{6}$ After treatment, most Touro patients were quickly discharged or else they died. The slaves fared much better than the whites admitted to Touro. The in-hospital mortality rate for white patients was 23.4 percent whereas only 6.3 percent of the slaves died at Touro (see Table 1). ${ }^{7}$ By way of comparison, the in-hospital mortality rate for white patients was more than three times greater than the mortality rate for enslaved patients. Other things equal, we expect the mortality rate of slaves to exceed the rate for whites. Slaves in the general population faced higher mortality rates than whites (Fogel and Engerman 1974, p. 126; Meeker 1976, p. 14; Steckel 1986, p. 284). In New Orleans, however, whites may have face higher mortality rates because of the presence of tropical diseases, especially yellow fever (Tunalı and Pritchett 1997; Warren 1997). In the following, we attempt to account for the racial difference in mortality rates by considering the maladies and characteristics of the patients admitted to Touro.

\footnotetext{
${ }^{6}$ Death rates at New Orleans Charity Hospital were often exceeded 20 percent (Matas 1962, p. 201).

7 The age and the length of residence in New Orleans were not recorded for 175 patients. After excluding these observations with missing values, our working sample of 1,405 patients includes 704 white patients and 701 slaves.
} 
Most patients were young adult males. Because it was not recorded at the time of admission, we infer gender from the patient's first name. Using this information, we identify 81 percent of the white patients and 77 percent of the slaves as males. Because males comprised only 41 percent of the New Orleans slave population in 1860, the large percentage of male patients is remarkable. ${ }^{8}$ In addition, the records of children and older adults are notably absent. Of those admitted to the hospital, less than 5 percent were children aged less than 15 years and less than 4 percent were adults aged 55 years or more. Possibly because of its proximity to the docks, Touro treated a relatively large number of male patients in their prime working years.

The admission form includes information about the patient's length of residence in New Orleans. For the slaves, the recorded length of residence ranged from one hour to fifty years, with an average length of 7.9 years and a median of four years. ${ }^{9}$ In comparison, the average length of residence for whites was 2.5 years and the median length was only two months. Perhaps more surprising is the recorded marital status of the slaves. Although slave marriages were not recognized by law, 29 percent of the slaves were recorded as married the comparable figure for whites was 23 percent. Controlling for variation in age and gender, relatively more slaves than whites were recorded as married, long-term residents of New Orleans.

Admissions and in-hospital morality rates varied more for whites than for slaves. As shown in Table 1, the yellow fever epidemic year of 1858 accounted for 41 percent of the total number of whites admitted to the hospital whereas the annual number of enslaved

\footnotetext{
${ }^{8} 1860$, the New Orleans enslaved population equaled 14,484, of whom 6,007 (or 41 percent) were male. For the white population, 52 percent were male (U.S. Bureau of the Census 1864, p. 193).

${ }^{9}$ In many cases, the recent arrivals were residents of other parishes, sent by their owners for treatment in the city.
} 
patients shows relatively little variation. In addition, most whites were admitted during the months of July through October, accounting for 63 percent of their hospital admissions. In contrast, the number of slaves admitted to the hospital shows relatively little seasonal variation. As discussed below, whites were more susceptible to yellow fever and these epidemics occurred during the late summer months. ${ }^{10}$

The leading causes for admission and in-hospital death are presented in Table 2. ${ }^{11}$ For slaves, the leading causes of admission were diarrhea and dysentery, respiratory diseases, accidents, and malaria. For whites, the leading causes for admission were yellow fever, diarrhea and dysentery, accidents, and malaria. Although diarrhea and dysentery were the leading causes of hospital admission, they were not leading causes of death for slaves. For slaves, the leading causes of in-hospital death were typhoid, respiratory diseases, dropsy (often symptomatic of congestive heart failure), and tuberculosis. The main cause of death for whites was yellow fever, followed by tuberculosis, diarrhea and dysentery, and diseases of the nervous system.

Yellow fever accounted for 73 percent of the deaths by whites in the hospital. In sharp contrast, only twenty slaves were diagnosed with yellow fever and none of them died. These statistics indicate that blacks were less susceptible to the disease than whites (see Savitt, 1978, pp. 240-246). Kiple and King (1981, p. 44) argue that blacks and whites were equally likely to contract yellow fever but that black victims suffered milder symptoms. Selective treatment of slaves might account for the lack of enslaved patients admitted for

\footnotetext{
${ }^{10}$ Other diseases also exhibit seasonal variation. Because residents spent more time indoors during the winter months, admissions for respiratory diseases were greatest during February and March. Admissions for malaria were greatest in August through October, months which generally coincide with increased mosquito activity. Finally, diseases of the digestive system were more common during the late summer months.

${ }^{11} \mathrm{We}$ adopt relatively broad disease categories in order to minimize the classification errors in Table 2 (Savitt 1978, pp. 138-145). For example, diarrhea and dysentery are combined into a single category because of the similarities of their symptoms. We suspect, however, that some classification errors remain. In our regression analysis, we use only three disease categories in order to minimize this measurement error.
} 
yellow fever - slaves with milder symptoms might have been treated at home. For those patients diagnosed with maladies other than yellow fever, the mortality rate for whites was 11.2 percent and the rate for slaves was 7.4 percent, a difference of 3.8 percentage points. Consequently, yellow fever was not the sole cause for the higher mortality rate of whites.

Differences in individual characteristics and maladies may account for the lower observed mortality rate for slaves. In the following, we estimate the determinants of inhospital mortality and analyze the results using Oaxaca-type decomposition based on probit estimates of mortality. We conclude with a discussion of sample selection bias among the slaves admitted to the hospital.

\section{Regression Analysis}

The probability of in-hospital death is estimated using a probit regression, where the dependent variable equals one if the patient died in Touro and zero otherwise. Independent variables indicate the gender, marital status, age, length of residence in New Orleans, year and month of admission and malady afflicting the patient. For the first specification of the regression, the records of both whites and slaves are combined in the sample and the effect of enslaved status is measured using an indicator variable. As shown in model (1), males were significantly less likely to die in Touro than female patients. The estimated marginal effect of maleness reduced the probability of in-hospital death by 7.1 percentage points. Increased mortality risk associated with childbirth may partially account for the increased probability of in-hospital death facing female patients. Most female patients, however, were admitted for reasons other than gender specific diseases which suggests that childbirth was not the primary cause of their higher mortality rate. 
Marital status may have also influenced the mortality rate of patients. Married patients may have been healthier and better able to resist life threatening illnesses. By indicating the presence of an alternative caregiver, marital status may indirectly affect the measured mortality rate of patients. If, for example, spouses cared for the moderately ill at home, then sample selection bias might have raised the mortality rate of those married patients admitted to the hospital. As seen in model (1), married patients had lower mortality rates, although the estimated regression coefficient was not statistically different from zero.

Young adults, aged 15 to 24 years and 25 to 34 years, faced lower probabilities of inhospital death than seniors, aged 55 years or older (the omitted category in the regression). Patients aged 35 years or more faced lower probabilities of in-hospital death relative to seniors, but higher probabilities of in-hospital death compared to children or young adults. None of these regression coefficients are statistically different from zero.

The patient's length of residence in New Orleans may have also influenced the probability of death. Tunalı and Pritchett (1997) argue that the length of residence serves as a proxy for prior exposure to yellow fever. Yellow fever was a frequent visitor to New Orleans during the nineteenth century. Because a previous bout of the disease confers immunity, the length of residence is negatively correlated with the probability of contracting yellow fever. Consistent with the conferred immunity hypothesis, most Touro patients suffering from yellow fever were recent arrivals to the city. For whites, the average length of residence for yellow fever patients was 1.2 years whereas the comparable figure for nonyellow fever patients was 2.4 years. Slaves also demonstrated a similar relationship between the length of residence in New Orleans and the incidence of yellow fever. The average length of residence for slaves diagnosed with yellow fever was 3.7 years. The comparable 
figure for enslaved patients not suffering from yellow fever is 6.8 years. The length of residence for yellow fever patients suggests that slaves (and whites) did not inherit immunity to the disease, but rather acquired it by previous exposure.

Although long-term residents were less likely to contract yellow fever, they were not less likely to die from the disease once they contracted it. The results from model (1) indicate little or no relationship between the length of residence and in-hospital mortality. Conditional on hospital admission (and controlling for the malady afflicting the patient), the length of residence in New Orleans has no effect on mortality.

Seasonal variation is estimated by indicator variables for the months of admission. Compared to the winter months of January and February, the mortality risk is significantly higher during the summer and fall. These seasonal effects are statistically and quantitatively significant. The estimated probability of death increases 12.6 percentage points during May and June, 26.3 percentage points during July and August, 13 percentage points during September and October and15.8 percent during November and December. In many cases, the patients admitted during the summer and fall contracted an infectious disease, significantly lowering their chances of survival. Temporal variation in mortality risk is also measured by covariates indicating the year of admission. Mortality risk was significantly higher during the yellow fever epidemic year of 1858 (relative to 1855, the reference category) and significantly less for the following year. These regression results are consistent with local variation in the disease environment.

Patients who contracted tropical diseases faced significantly higher probabilities of death than other patients. Tropical diseases include yellow fever, diarrhea and dysentery, malaria, typhoid, tuberculosis, unclassified fevers, and cholera (World Health Organization 
2007). Other things equal, contracting a tropical disease increased the probability of death by 8.2 percentage points.

The final covariate in model (1) indicates the enslaved status of the patient. The estimated regression coefficient is large, negative, and statistically different from zero. The estimated marginal effect of enslaved status is negative 8.9 percentage points, indicating that slaves faced lower mortality risks than whites. ${ }^{12}$

For model (1), we pooled the hospital records of whites and slaves and constrain the estimated regression coefficients to be equal for both races. As discussed earlier (and shown in Table 2), whites showed greater susceptibilities to tropical diseases than slaves and, consequently, the estimate coefficient for this variable should be greater for whites than for slaves. A likelihood-ratio test for pooling the samples is rejected at the 1 percent level of significance. In models (2) and (3) of Table 3, we estimate regressions for whites and slaves separately, allowing the regression coefficients to differ. Rather than discussing every estimate for these two models, we highlight their main differences.

The regression results for models (2) and (3) indicate that a longer duration in New Orleans reduced the mortality risk for slaves but not for whites, a surprising result because residency serves as a proxy for immunity to yellow fever. Because whites were more susceptible to yellow fever, we anticipated that they would benefit more from a longer

\footnotetext{
${ }^{12}$ Racial differences in treatments may account for the observed difference in the mortality rates of slaves and freemen. Unfortunately, the level of treatment received by patients is unobserved. To the extent that medical treatments were disease specific (for example, doctors setting broken bones), we control for possible racial differences in treatment by including indicator variables for disease in our regression equation. In addition, feepaying patients may have received better care from the hospital than charity patients which could have affected health outcomes. Nearly all slaves were fee-paying patients and approximately one-fourth of the whites were charity patients. If charity patients suffered higher mortality rates than other patients, then this might account for the racial difference in mortality rates observed at Touro. To investigate this possibility, we estimate a probit model of mortality with a covariate indicating charity status. As shown in Table 5 of the appendix, charity patients faced similar mortality risks as other fee-paying patients. Consequently, the charity status of white patients does not account for the racial difference in mortality rates observed at Touro.
} 
duration in New Orleans. These regression coefficients, however, are not statistically different from zero.

The mortality risks for whites and slaves continue to show considerable seasonal variation. The marginal effects of the month of admission are largest for the white patients. For example, admission during July or August increased mortality risk for whites by 41 percentage points whereas the increased mortality risk for slaves was 14 percent. These coefficients, however, are not statistically different from each other.

As anticipated, the variable indicating a tropical disease had a much greater effect for whites than for slaves. For the sample of white patients, the estimated coefficient for tropical diseases is large and statistically different from zero. For the sample of slaves, however, being afflicted with a tropical disease actually lower the patient's mortality risk (relative to unknown maladies, the reference category). For patients who contracted a tropical disease, whites faced higher probabilities of death, which contributed to their higher in-hospital mortality rate.

\section{Accounting for the Difference in Mortality Rates}

Why did relatively more whites die in Touro? In the previous section, we estimated the mortality rates for whites and slaves using their individual characteristics, maladies, and dates of admission. In this section, we calculate Oaxaca-type decomposition based on our earlier probit estimates to analyze the observed difference in mortality rates between whites and slaves.

Following Oaxaca (1973), we propose two separate effects to account for the difference in mortality rates: (1) the Characteristics Effect and (2) the Coefficients Effect. 
The characteristics effect measures the effect of differences in group characteristics or attributes on the probability of survival. For example, suppose that older patients faced greater mortality risks than younger patients. If one group was older on average than another, then the characteristic effect would measure the effect of increased age on the difference in mortality rates between the two comparison groups.

The coefficients effect measures the different effectiveness of patient characteristics on the probability of survival. As previously presented in Table 3, we use probit regressions to estimate the effect of patient characteristics on the probability of survival. We find, for example, that slaves had greater resistance to tropical diseases than whites. Even though whites and slaves may have been afflicted by the same diseases, the impact of those diseases may differ, leading to different mortality rates. The coefficients effect measures the difference in the estimated probit coefficients and its effect on the difference in mortality rates between the two comparison groups.

We implement Oaxaca-type decomposition equations for discrete dependent variables as suggested by Yun (2004). Previously, the difference in the mean value of a binary dependent variable was decomposed by so-called "simulation" (see Abowd and Killingsworth 1984; Fairlie 2005). In these analyses, logits or probits were estimated for each group, and one groups' coefficients substituted with those of the other group in order to calculate a counter-factual predicted probability. The coefficients effect equaled the difference between the counter-factual prediction and the observed probability for the former group, holding characteristics constant. This simulation method, however, is not only tedious but also problematic since it may be sensitive to the order of switching (see Ham, Svejnar and Terrell 1998, p. 1137 for a discussion of path-dependency). The decomposition method 
proposed by Yun (2004) provides a systematic treatment for differences in binary outcomes free from path dependency.

\subsection{Decomposing the Difference in Mortality Rates using Probit Estimates}

Our analysis decomposes the in-hospital mortality gap into characteristics and coefficients effects at different levels of aggregation. As discussed in the previous section, we estimate probit models of mortality incidence for whites and slaves separately, where the dependent variable has a value of one if the patient died. The likelihood of mortality for patient $i$ is estimated by $\Phi\left(X_{i} \beta\right)$, where $X_{i}$ is a $1 \times K$ vector of independent variables, $\beta$ is a $K \times 1$ vector of coefficients, and $\Phi$ is the standard normal distribution function. Asymptotically, the observed mortality rate is equal to the sample average of the patient's mortality likelihood, or $\bar{M}=\overline{\Phi(X \beta)}=\frac{1}{N} \sum_{i=1}^{N} \Phi\left(X_{i} \beta\right)$. Algebraically, the differences in the average likelihood of mortality between whites (group $A$ ) and slaves (group $B$ ) may be decomposed as following;

$$
\bar{M}_{A}-\bar{M}_{B}=\left[\overline{\Phi\left(X_{A} \beta_{A}\right)}-\overline{\Phi\left(X_{B} \beta_{A}\right)}\right]+\left[\overline{\Phi\left(X_{B} \beta_{A}\right)}-\overline{\Phi\left(X_{B} \beta_{B}\right)}\right]
$$

where the first and the second components in the right hand side represent the characteristics effect and coefficients effect; "over bar" represents the value of the sample's average.

The above decomposition gives us the overall coefficients and characteristics effects. To find the relative contribution of each variable to the predicted mortality gap, in terms of characteristics and coefficients effects, we employ a decomposition equation proposed by Yun $(2004){ }^{13}$

\footnotetext{
${ }^{13}$ In order to obtain a proper weight, the following approximations are used; first, an
} 


$$
\bar{M}_{A}-\bar{M}_{B}=\sum_{k=1}^{K} W_{\Delta X}^{k}\left[\overline{\Phi\left(X_{A} \beta_{A}\right)}-\overline{\Phi\left(X_{B} \beta_{A}\right)}\right]+\sum_{k=1}^{K} W_{\Delta \beta}^{k}\left[\overline{\Phi\left(X_{B} \beta_{A}\right)}-\overline{\Phi\left(X_{B} \beta_{B}\right)}\right],
$$

where $W_{\Delta X}^{k}=\frac{\left(\bar{X}_{A}^{k}-\bar{X}_{B}^{k}\right) \beta_{A}^{k}}{\left(\bar{X}_{A}-\bar{X}_{B}\right) \beta_{A}}, W_{\Delta \beta}^{k}=\frac{\bar{X}_{B}^{k}\left(\beta_{A}^{k}-\beta_{B}^{k}\right)}{\bar{X}_{B}\left(\beta_{A}-\beta_{B}\right)}$, and $\sum_{k=1}^{K} W_{\Delta X}^{k}=\sum_{k=1}^{K} W_{\Delta \beta}^{k}=1$, where $\bar{X}_{A}^{k}$ and $\bar{X}_{B}^{k}$ are average values of explanatory variables $k$ for groups $A$ and $B$, respectively. ${ }^{14}$

\subsection{Explaining Differences in Mortality Rates}

The results of our decomposition analysis are presented in Table 4. We first discuss the aggregate characteristics and coefficients effects and then the contribution of subaggregate characteristics and coefficients effects to the overall mortality gap. As presented in the first row of the table, the aggregate characteristics effect accounts for 50.93 percent of the difference in mortality rates between whites and slaves whereas the aggregate coefficients

approximation of the value of the average of the function, $\overline{\Phi(X \beta)}$, with that of the function evaluated at the average value of exogenous variables, $\Phi(\bar{X} \beta)$; second, a first order Taylor expansion to linearize the characteristics and coefficients effects around $\bar{X}_{A} \beta_{A}$ and $\bar{X}_{B} \beta_{B}$. See Yun (2004) for details.

14 For computing asymptotic standard errors of the characteristics and coefficients effects, see Yun (2005a). We deal with robustness issues, known as the index or parameterization problem and the identification problem in detailed decompositions. A decomposition equation with a different parameterization, that

is, $\left[\overline{\Phi\left(X_{A} \beta_{B}\right)}-\overline{\Phi\left(X_{B} \beta_{B}\right)}\right]+\left[\overline{\Phi\left(X_{A} \beta_{A}\right)}-\overline{\Phi\left(X_{A} \beta_{B}\right)}\right]$, is possible; our results with it are not substantially different from those presented here and are available from the authors upon request. Another issue when interpreting the decomposition results is that the coefficients effect in the detailed decomposition is not invariant to the choice of omitted groups when dummy variables are used (see Oaxaca and Ransom 1999, for details of this issue). We follow a solution suggested by Yun (2005b) that, if alternative reference groups yield different estimates of the coefficients effects for each individual variable, it is natural to obtain estimates of the coefficients effects for every possible specification of the reference groups and take the average of the estimates of the coefficients effects with various reference groups as the "true" contributions of individual variables to differentials. While appearing cumbersome, this can be accomplished with a single estimation. We can transform our probit estimates into a normalized equation and use the normalized equation for our decomposition. 
effect accounts for 49.07 percent of the difference in mortality. Both characteristics effects and coefficients effects are statistically different from zero at the 1 percent level of significance. These estimates may be interpreted as follows: If the covariates presented in Table 3 had the same effect on the mortality of either group, or in other words, if the probit coefficients estimated in models (2) and (3) had been equal, the mortality rate gap would have been reduced by 49.07 percent. On the other hand, if whites and slaves had the same characteristics, then 50.93 percent of the mortality rate gap would have disappeared.

Sub-aggregate characteristics and coefficients effects are also presented in Table $4 .{ }^{15}$ Seasonal variation in hospital admissions accounts for a large part of the observed difference in mortality rates. The characteristics effect for month of admission equals 40.07 percent and is statistically significant at 1 percent level. Relatively more whites than slaves were admitted during the summer months, when mortality rates were high, which increases the size of the mortality gap. The coefficients effect for the month of admission is small, negative, and not statistically different from zero. The negative coefficients effect adversely affects the mortality of slaves and contributes to a smaller mortality gap.

The malady afflicting the patients also contributed to the disparity in mortality rates. The characteristics effect is large, accounts for 26.67 percent of total mortality rate gap, and it is statistically significant at 1 percent level. Relatively more whites than slaves were admitted with tropical diseases which contribute to a larger mortality gap. Surprisingly, the coefficients effects is small (5.58 percent) and not statistically significant. As discussed previously, whites had higher in-hospital mortality rates from tropical diseases than slaves, which other things equal, should have increased the size of the mortality gap. Slaves, however, suffered higher mortality rates from unknown diseases, which tends to offset the

\footnotetext{
${ }^{15}$ Characteristics and coefficients effects for individual covariates are presented in the appendix.
} 
coefficients effect from tropical diseases.

The characteristics effects of the other demographic variables, such as gender and age, are relatively small. Indeed, the covariates included in our regressions account for only a fraction of the observed mortality gap between slaves and whites. The coefficients effect of the intercept, which measures the residual variation in mortality, accounts for 63 percent of the mortality gap and is statistically different from zero at the 1 percent level. This result suggests that the patient's enslaved status (in contrast to other characteristics) was the primary reason for his lower mortality rate.

Slaves had shorter life expectancies and received less hospital care than whites. Their lower in-hospital mortality rate suggests that the selection process by which slaves were admitted to the hospital differed from that of whites and that the slaves admitted to the hospital were healthier than the whites. In the conclusion, we briefly discuss the economic motive for the selective medical treatment of slaves.

\section{Discussion}

Why provide hospital care for slaves? In addition to humanitarian reasons, paternalism may have motivated some owners to provide medical care for their slaves. Under a doctrine of paternalism, slaves were members of the owner's extended family and the owner took care of them. Viewed differently, paternalism was an implicit, long-term contract between the owner and the slave. In exchange for his labor, the owner promised to provide the slave with a lifetime of food, shelter, clothing, and health care (Genovese 1976, pp. 3-7; Stampp 1956, 322-330; Fogel and Engerman 1974, p. 73). An owner who reneged 
on this implicit contract might lose credibility with his slaves, increasing the cost of obtaining labor from them.

Louisiana law required that owners provide care for their ailing slaves. According to sections 4 and 5 of the Black Code (Louisiana 1806, p. 101), "slaves disabled through old age, sickness, or any other cause, whether their disease be incurable or not, shall be fed and maintained by their owners..." Furthermore, every owner was required "to procure to his sick slaves all kinds of temporal and spiritual assistance which their situation may require." Owners found guilty of violating these sections of the Code were subject to fines of twenty five dollars for every offense. There is no evidence, however, that these laws were enforced.

By contemporary or current standards, slaves were expensive. In 1860, the average price of a prime-aged male equaled $\$ 1,800$ in New Orleans, an amount equal to more than ten times contemporary per capita income. Depending on the choice of index, the real price of a slave ranged from the current price of a luxury automobile to that of a modest home (Deyle 2005, p. 70). From the viewpoint of the owner, the death of valuable slave was a devastating financial loss - This potential loss created an incentive for owners to provide healthcare for their slaves.

The price of a slave reflected his current health and future productivity. For a slave with a life threatening illness, his expected price equaled the product of his probability of survival and the price of the slave if healthy. Market data from New Orleans indicates that an ailing slave sold at a discount compared to the prices of healthy slaves (Fogel 1989, p. 68; Kotlikoff 1992, p. 46). Curing an ailing slave created a capital gain for the owner.

As an investment decision, the in-hospital death of a slave was a financial mistake. The owner's marginal benefit of medical care equals the product of the increased probability 
of survival and the slave's price if healthy. The owner would seek medical treatment for the slave if the marginal benefit exceeded the cost of hospitalization. If an owner thought a case was hopeless, a "perversion of the property interest" might prevent a sick slave from receiving medical attention (Shryock 1930, p. 174). In addition, hopeless cases may have been discharged early by the hospital, if only to have the slaves die elsewhere. After all, why pay for the care of someone with little chance of survival? Instead, an owner sought treatment for those slaves with better prospects for recovery. The absence of these hopeless cases may account for the low in-hospital mortality rate for enslaved patients. 
Table 1

Descriptive Statistics, Touro Hospital, 1855-1860, by Race

\begin{tabular}{|c|c|c|c|c|}
\hline \multirow[b]{2}{*}{ Covariate $(1=$ yes, $0=$ no $)$} & \multicolumn{2}{|c|}{ Whites } & \multicolumn{2}{|c|}{ Slaves } \\
\hline & Mean & $\begin{array}{l}\text { Standard } \\
\text { deviation }\end{array}$ & Mean & $\begin{array}{l}\text { Standard } \\
\text { deviation }\end{array}$ \\
\hline \multicolumn{5}{|l|}{ Dependent variable } \\
\hline Died in Hospital & 0.234 & 0.424 & 0.063 & 0.243 \\
\hline \multicolumn{5}{|l|}{ Gender and marital status } \\
\hline Male & 0.810 & 0.393 & 0.769 & 0.422 \\
\hline Married & 0.227 & 0.419 & 0.288 & 0.453 \\
\hline \multicolumn{5}{|l|}{ Age of patient } \\
\hline Aged 0 to 14 years & 0.037 & 0.189 & 0.043 & 0.203 \\
\hline Aged 15 to 24 years & 0.389 & 0.488 & 0.305 & 0.461 \\
\hline Aged 25 to 34 years & 0.354 & 0.478 & 0.372 & 0.484 \\
\hline Aged 35 to 44 years & 0.135 & 0.342 & 0.171 & 0.377 \\
\hline Aged 45 to 54 years & 0.058 & 0.234 & 0.068 & 0.253 \\
\hline Aged 55 years or more & 0.027 & 0.162 & 0.040 & 0.196 \\
\hline \multicolumn{5}{|l|}{ Residence in New Orleans } \\
\hline New Orleans resident less than 1 year & 0.722 & 0.449 & 0.389 & 0.488 \\
\hline New Orleans resident 1 to 4 years & 0.163 & 0.370 & 0.165 & 0.372 \\
\hline New Orleans resident 5 years or more & 0.115 & 0.319 & 0.445 & 0.497 \\
\hline \multicolumn{5}{|l|}{ Month of admission } \\
\hline Admitted in January or February & 0.118 & 0.323 & 0.127 & 0.333 \\
\hline Admitted in March or April & 0.081 & 0.273 & 0.228 & 0.420 \\
\hline Admitted in May or June & 0.074 & 0.262 & 0.168 & 0.374 \\
\hline Admitted in July or August & 0.250 & 0.433 & 0.171 & 0.377 \\
\hline Admitted in September or October & 0.381 & 0.486 & 0.174 & 0.379 \\
\hline Admitted in November or December & 0.097 & 0.296 & 0.131 & 0.338 \\
\hline \multicolumn{5}{|l|}{ Cause for admission } \\
\hline Afflicted with unknown disease & 0.142 & 0.349 & 0.210 & 0.407 \\
\hline Afflicted with a tropical disease & 0.639 & 0.481 & 0.328 & 0.470 \\
\hline Afflicted with a non-tropical disease & 0.219 & 0.414 & 0.462 & 0.499 \\
\hline \multicolumn{5}{|l|}{ Year of admission } \\
\hline Admitted in 1855 & 0.237 & 0.426 & 0.073 & 0.260 \\
\hline Admitted in 1856 & 0.121 & 0.326 & 0.204 & 0.403 \\
\hline Admitted in 1857 & 0.085 & 0.279 & 0.288 & 0.453 \\
\hline Admitted in 1858 & 0.413 & 0.493 & 0.211 & 0.408 \\
\hline Admitted in 1859 & 0.104 & 0.305 & 0.154 & 0.361 \\
\hline Admitted in 1860 & 0.040 & 0.196 & 0.070 & 0.255 \\
\hline Sample size & 704 & & 701 & \\
\hline
\end{tabular}

Source: Touro Infirmary Admission Records, New Orleans, LA. 
Note: Tropical diseases are defined as yellow fever, diarrhea and dysentery, malaria, typhoid, tuberculosis, unclassified fevers, and cholera. 
Table 2

Leading Causes for Admissions and In-hospital Mortality, Touro Infirmary, 1855-1860, by Race

\begin{tabular}{|c|c|c|c|c|}
\hline \multirow[b]{2}{*}{ Malady } & \multicolumn{2}{|c|}{ Whites } & \multicolumn{2}{|c|}{ Slaves } \\
\hline & Admits & Mort. rate & Admits & Mort. rate \\
\hline Yellow fever & 331 & $38.37 \%$ & 20 & $0.00 \%$ \\
\hline Diarrhea \& dysentery & 44 & $13.64 \%$ & 140 & $2.86 \%$ \\
\hline Accident $^{1}$ & 43 & $0.00 \%$ & 76 & $3.95 \%$ \\
\hline Respiratory disease $^{2}$ & 19 & $5.26 \%$ & 86 & $6.98 \%$ \\
\hline Malaria $^{3}$ & 40 & $7.50 \%$ & 43 & $2.33 \%$ \\
\hline Digestive system disease ${ }^{4}$ & 27 & $11.11 \%$ & 38 & $10.53 \%$ \\
\hline Sexually transmitted disease ${ }^{5}$ & 21 & $0.00 \%$ & 38 & $5.26 \%$ \\
\hline Nervous system disease $^{6}$ & 14 & $35.71 \%$ & 31 & $9.68 \%$ \\
\hline Maternity/female diseases ${ }^{7}$ & 6 & $0.00 \%$ & 30 & $6.67 \%$ \\
\hline Skin disease ${ }^{8}$ & 12 & $0.00 \%$ & 22 & $4.55 \%$ \\
\hline Typhoid $^{9}$ & 12 & $8.33 \%$ & 22 & $31.82 \%$ \\
\hline Rheumatism $^{10}$ & 10 & $0.00 \%$ & 22 & $0.00 \%$ \\
\hline Tuberculosis $^{11}$ & 21 & $52.38 \%$ & 11 & $45.45 \%$ \\
\hline Fever, unclassified ${ }^{12}$ & 9 & $22.22 \%$ & 17 & $0.00 \%$ \\
\hline Debility $^{13}$ & 5 & $40.00 \%$ & 16 & $6.25 \%$ \\
\hline Abscess & 4 & $0.00 \%$ & 15 & $0.00 \%$ \\
\hline Dropsy ${ }^{14}$ & 4 & $50.00 \%$ & 13 & $46.15 \%$ \\
\hline Indisposition & 5 & $0.00 \%$ & 12 & $0.00 \%$ \\
\hline Cholera $^{15}$ & 8 & $25.00 \%$ & 6 & $0.00 \%$ \\
\hline Intemperance ${ }^{16}$ & 9 & $11.11 \%$ & 4 & $0.00 \%$ \\
\hline Other maladies & 47 & $10.64 \%$ & 67 & $7.46 \%$ \\
\hline Unknown/unrecorded maladies & 58 & $5.17 \%$ & 102 & $9.80 \%$ \\
\hline All maladies & 749 & $23.23 \%$ & 831 & $7.22 \%$ \\
\hline
\end{tabular}

Source: Touro Infirmary admission records.

Note: Due to missing values for age and/or length of residence in New Orleans, 175 records were excluded from the samples.

\footnotetext{
${ }^{1}$ Burns, concussions, cuts, dislocations, fractures, frostbite, gunshot wounds, hernias, insidious wounds, injuries, lacerations, punctures, and sprains.

${ }_{2}^{2}$ Asthma, bronchitis, catarrh, pleurisy, and pneumonia.

${ }^{3}$ Intermittent and remittent fever.

${ }^{4}$ Cholic, colitis, constipation, dyspepsia, enteritis, flatulence, gastritis, gastrodynia, gout, hemorrhoids, indigestion, jaundice, peritonitis, ulcer, and ulceration of rectum.

${ }^{5}$ Gonorrhea and syphilis.

${ }^{6}$ Apoplexy, chorea, congestion of brain, convulsions, dirt-eater, epilepsy, hemiplegia, hysteria, mania, neuralgia, paralysis, ramollissement, sciatica, and vertigo.

${ }^{7}$ Abortion, amenorrhea, dysmenorrhea, leucorrhea, menorrhagia, pregnancy, and prolapsed uterus.

${ }^{8}$ Bed sore, eczema, erithema, erysipelas, ground itch, necrosis, poison oak, psoriasis, roseola, rubeola, and urticaria.

${ }^{9}$ Bilious remittent, continued and typhoid fever.

${ }^{10}$ Rheumatism and synovitis.

${ }^{11}$ Consumption, homoptysis, phthisis, and scrofula.

${ }^{12}$ Chagres, congestive, and ephemoral fevers.

${ }_{14}^{13}$ Anemia and debility.

${ }^{14}$ Anasarca, ascites, and dropsy.

${ }^{15}$ Cholera and cholera morbus.

${ }^{16}$ Delirium tremens, mania a potu, and periodic drunk.
} 
Table 3

Probit Regression Results, Touro Infirmary, 1855-1860

\begin{tabular}{|c|c|c|c|c|c|c|}
\hline \multirow[b]{2}{*}{ Covariate ( $1=y e s, 0=$ no) } & \multicolumn{2}{|c|}{ (1) Combined } & \multicolumn{2}{|c|}{ (2) Whites } & \multicolumn{2}{|c|}{ (3) Slaves } \\
\hline & Coefficient & $\begin{array}{c}\text { Marginal } \\
\text { effect }\end{array}$ & Coefficient & $\begin{array}{l}\text { Marginal } \\
\text { effect }\end{array}$ & Coefficient & $\begin{array}{c}\text { Marginal } \\
\text { effect }\end{array}$ \\
\hline Intercept & $\begin{array}{c}-1.415^{* * *} \\
(0.340)\end{array}$ & N.M. & $\begin{array}{c}-1.795^{* * *} \\
(0.538)\end{array}$ & N.M. & $\begin{array}{c}-2.005^{* * *} \\
(0.559)\end{array}$ & N.M. \\
\hline \multicolumn{7}{|l|}{ Gender and marital status } \\
\hline Male & $\begin{array}{c}-0.360 * * * \\
(0.108)\end{array}$ & $\begin{array}{c}-0.071 \\
(0.024)\end{array}$ & $\begin{array}{l}-0.247^{*} \\
(0.142)\end{array}$ & $\begin{array}{c}-0.066 \\
(0.041)\end{array}$ & $\begin{array}{c}-0.453^{* * *} \\
(0.175)\end{array}$ & $\begin{array}{c}-0.052 \\
(0.025)\end{array}$ \\
\hline Married & $\begin{array}{l}-0.065 \\
(0.116)\end{array}$ & $\begin{array}{l}-0.011 \\
(0.019)\end{array}$ & $\begin{array}{c}0.057 \\
(0.157)\end{array}$ & $\begin{array}{c}0.014 \\
(0.040)\end{array}$ & $\begin{array}{c}-0.204 \\
(0.189)\end{array}$ & $\begin{array}{l}-0.017 \\
(0.015)\end{array}$ \\
\hline \multicolumn{7}{|l|}{ Age of patient } \\
\hline Aged 0 to 14 years & $\begin{array}{l}-0.156 \\
(0.342)\end{array}$ & $\begin{array}{l}-0.025 \\
(0.049)\end{array}$ & $\begin{array}{c}-0.363 \\
(0.457)\end{array}$ & $\begin{array}{l}-0.076 \\
(0.078)\end{array}$ & $\begin{array}{c}0.196 \\
(0.581)\end{array}$ & $\begin{array}{c}0.021 \\
(0.072)\end{array}$ \\
\hline Aged 15 to 24 years & $\begin{array}{l}-0.246 \\
(0.262)\end{array}$ & $\begin{array}{c}-0.041 \\
(0.041)\end{array}$ & $\begin{array}{l}-0.532 \\
(0.367)\end{array}$ & $\begin{array}{l}-0.125 \\
(0.081)\end{array}$ & $\begin{array}{c}0.283 \\
(0.431)\end{array}$ & $\begin{array}{c}0.029 \\
(0.049)\end{array}$ \\
\hline Aged 25 to 34 years & $\begin{array}{c}-0.234 \\
(0.256)\end{array}$ & $\begin{array}{l}-0.039 \\
(0.041)\end{array}$ & $\begin{array}{l}-0.510 \\
(0.365)\end{array}$ & $\begin{array}{l}-0.118 \\
(0.077)\end{array}$ & $\begin{array}{c}0.366 \\
(0.410)\end{array}$ & $\begin{array}{c}0.037 \\
(0.046)\end{array}$ \\
\hline Aged 35 to 44 years & $\begin{array}{l}-0.036 \\
(0.265)\end{array}$ & $\begin{array}{l}-0.006 \\
(0.045)\end{array}$ & $\begin{array}{l}-0.276 \\
(0.380)\end{array}$ & $\begin{array}{l}-0.062 \\
(0.076)\end{array}$ & $\begin{array}{c}0.534 \\
(0.425)\end{array}$ & $\begin{array}{c}0.067 \\
(0.070)\end{array}$ \\
\hline Aged 45 to 54 years & $\begin{array}{c}0.065 \\
(0.302)\end{array}$ & $\begin{array}{c}0.012 \\
(0.057)\end{array}$ & $\begin{array}{l}-0.279 \\
(0.427)\end{array}$ & $\begin{array}{l}-0.061 \\
(0.081)\end{array}$ & $\begin{array}{c}0.814 \\
(0.476)\end{array}$ & $\begin{array}{c}0.132 \\
(0.116)\end{array}$ \\
\hline \multicolumn{7}{|l|}{ Residence in New Orleans } \\
\hline $\begin{array}{l}\text { New Orleans resident, } 1 \text { to } \\
4 \text { years }\end{array}$ & $\begin{array}{l}-0.016 \\
(0.124)\end{array}$ & $\begin{array}{l}-0.003 \\
(0.021)\end{array}$ & $\begin{array}{c}0.096 \\
(0.153)\end{array}$ & $\begin{array}{c}0.025 \\
(0.040)\end{array}$ & $\begin{array}{l}-0.320 \\
(0.224)\end{array}$ & $\begin{array}{l}-0.025 \\
(0.015)\end{array}$ \\
\hline $\begin{array}{l}\text { New Orleans resident, } 5 \\
\text { years or more }\end{array}$ & $\begin{array}{l}-0.003 \\
(0.132)\end{array}$ & $\begin{array}{l}-0.001 \\
(0.023)\end{array}$ & $\begin{array}{l}0.305 \\
(0.188)\end{array}$ & $\begin{array}{l}0.085 \\
(0.057)\end{array}$ & $\begin{array}{l}-0.210 \\
(0.174)\end{array}$ & $\begin{array}{l}-0.019 \\
(0.015)\end{array}$ \\
\hline \multicolumn{7}{|l|}{ Month of admission } \\
\hline $\begin{array}{l}\text { Admitted in March or } \\
\text { April }\end{array}$ & $\begin{array}{l}-0.089 \\
(0.254)\end{array}$ & $\begin{array}{l}-0.015 \\
(0.041)\end{array}$ & $\begin{array}{l}-0.538 \\
(0.483)\end{array}$ & $\begin{array}{l}-0.106 \\
(0.070)\end{array}$ & $\begin{array}{l}-0.006 \\
(0.282)\end{array}$ & $\begin{array}{l}-0.001 \\
(0.026)\end{array}$ \\
\hline Admitted in May or June & $\begin{array}{c}0.563^{* *} \\
(0.238)\end{array}$ & $\begin{array}{l}0.126 \\
(0.064)\end{array}$ & $\begin{array}{c}0.646 \\
(0.435)\end{array}$ & $\begin{array}{c}0.201 \\
(0.154)\end{array}$ & $\begin{array}{l}0.518^{*} \\
(0.289)\end{array}$ & $\begin{array}{c}0.064 \\
(0.045)\end{array}$ \\
\hline Admitted in July or August & $\begin{array}{c}1.068^{* * *} \\
(0.211)\end{array}$ & $\begin{array}{c}0.263 \\
(0.063)\end{array}$ & $\begin{array}{c}1.318^{* * *} \\
(0.363)\end{array}$ & $\begin{array}{c}0.411 \\
(0.117)\end{array}$ & $\begin{array}{c}0.907^{* * *} \\
(0.295)\end{array}$ & $\begin{array}{c}0.137 \\
(0.062)\end{array}$ \\
\hline $\begin{array}{l}\text { Admitted in September or } \\
\text { October }\end{array}$ & $\begin{array}{c}0.627 * * * \\
(0.217)\end{array}$ & $\begin{array}{c}0.130 \\
(0.051)\end{array}$ & $\begin{array}{l}0.906^{* *} \\
(0.367)\end{array}$ & $\begin{array}{c}0.247 \\
(0.101)\end{array}$ & $\begin{array}{c}0.091 \\
(0.352)\end{array}$ & $\begin{array}{c}0.009 \\
(0.036)\end{array}$ \\
\hline $\begin{array}{l}\text { Admitted in November or } \\
\text { December }\end{array}$ & $\begin{array}{c}0.672^{* * *} \\
(0.243)\end{array}$ & $\begin{array}{l}0.158 \\
(0.071)\end{array}$ & $\begin{array}{c}0.632 \\
(0.404)\end{array}$ & $\begin{array}{l}0.194 \\
(0.141)\end{array}$ & $\begin{array}{c}0.819 * * * \\
(0.303)\end{array}$ & $\begin{array}{c}0.124 \\
(0.065)\end{array}$ \\
\hline \multicolumn{7}{|l|}{ Malady } \\
\hline $\begin{array}{l}\text { Afflicted with a tropical } \\
\text { disease }\end{array}$ & $\begin{array}{c}0.465 * * * \\
(0.159)\end{array}$ & $\begin{array}{c}0.082 \\
(0.029)\end{array}$ & $\begin{array}{c}0.848^{* * *} \\
(0.245)\end{array}$ & $\begin{array}{c}0.188 \\
(0.048)\end{array}$ & $\begin{array}{l}-0.054 \\
(0.237)\end{array}$ & $\begin{array}{l}-0.005 \\
(0.021)\end{array}$ \\
\hline $\begin{array}{l}\text { Afflicted with a non- } \\
\text { tropical disease }\end{array}$ & $\begin{array}{l}0.157 \\
(0.167)\end{array}$ & $\begin{array}{l}0.028 \\
(0.031)\end{array}$ & $\begin{array}{c}0.298 \\
(0.269)\end{array}$ & $\begin{array}{l}0.080 \\
(0.078)\end{array}$ & $\begin{array}{l}-0.073 \\
(0.195)\end{array}$ & $\begin{array}{l}-0.007 \\
(0.018)\end{array}$ \\
\hline Year of Admission & & & & & & \\
\hline Admitted in 1856 & $\begin{array}{l}-0.258 \\
(0.192)\end{array}$ & $\begin{array}{l}-0.040 \\
(0.026)\end{array}$ & $\begin{array}{l}-0.320 \\
(0.292)\end{array}$ & $\begin{array}{l}-0.071 \\
(0.054)\end{array}$ & $\begin{array}{c}0.072 \\
(0.343)\end{array}$ & $\begin{array}{c}0.007 \\
(0.034)\end{array}$ \\
\hline Admitted in 1857 & $\begin{array}{c}0.101 \\
(0.170)\end{array}$ & $\begin{array}{l}0.018 \\
(0.032)\end{array}$ & $\begin{array}{c}0.263 \\
(0.228)\end{array}$ & $\begin{array}{c}0.072 \\
(0.068)\end{array}$ & $\begin{array}{c}0.152 \\
(0.332)\end{array}$ & $\begin{array}{l}0.015 \\
(0.034)\end{array}$ \\
\hline Admitted in 1858 & $\begin{array}{c}0.370^{* * *} \\
(0.132)\end{array}$ & $\begin{array}{c}0.071 \\
(0.028)\end{array}$ & $\begin{array}{l}0.236 \\
(0.160)\end{array}$ & $\begin{array}{l}0.060 \\
(0.042)\end{array}$ & $\begin{array}{l}0.558^{*} \\
(0.321)\end{array}$ & $\begin{array}{l}0.068 \\
(0.050)\end{array}$ \\
\hline
\end{tabular}


Table 3

Probit Regression Results, Touro Infirmary, 1855-1860

\begin{tabular}{|c|c|c|c|c|c|c|}
\hline \multirow[b]{2}{*}{ Covariate $(1=y e s, 0=$ no) } & \multicolumn{2}{|c|}{ (1) Combined } & \multicolumn{2}{|c|}{ (2) Whites } & \multicolumn{2}{|c|}{ (3) Slaves } \\
\hline & Coefficient & $\begin{array}{c}\text { Marginal } \\
\text { effect }\end{array}$ & Coefficient & $\begin{array}{c}\text { Marginal } \\
\text { effect }\end{array}$ & Coefficient & $\begin{array}{c}\text { Marginal } \\
\text { effect }\end{array}$ \\
\hline Admitted in 1859 & $\begin{array}{c}-0.480 * * \\
(0.214)\end{array}$ & $\begin{array}{c}-0.066 \\
(0.022)\end{array}$ & $\begin{array}{c}-0.286 \\
(0.269)\end{array}$ & $\begin{array}{c}-0.064 \\
(0.052)\end{array}$ & $\begin{array}{c}-0.432 \\
(0.434)\end{array}$ & $\begin{array}{c}-0.031 \\
(0.023)\end{array}$ \\
\hline Admitted in 1860 & $\begin{array}{c}0.441 \\
(0.286)\end{array}$ & $\begin{array}{c}0.097 \\
(0.076)\end{array}$ & $\begin{array}{c}0.476 \\
(0.445)\end{array}$ & $\begin{array}{c}0.143 \\
(0.153)\end{array}$ & $\begin{array}{c}0.637 \\
(0.428)\end{array}$ & $\begin{array}{c}0.092 \\
(0.086)\end{array}$ \\
\hline $\begin{array}{l}\text { Status of patient } \\
\text { Slave }\end{array}$ & $\begin{array}{c}-0.507^{* * *} \\
(0.114)\end{array}$ & $\begin{array}{c}-0.089 \\
(0.020)\end{array}$ & & & & \\
\hline Sample size & 1405 & & 704 & & 701 & \\
\hline Log-likelihood & -478.010 & & -316.510 & & -144.853 & \\
\hline Pseudo R-squared & 0.191 & & 0.174 & & 0.119 & \\
\hline
\end{tabular}

Source: Touro Hospital Admission Records.

Note: N.M. indicates that the statistic is not meaningful. Tropical diseases include yellow fever, diarrhea and dysentery, malaria, typhoid, tuberculosis, unclassified fevers, and cholera Standard errors are reported in parentheses. The omitted category refers to an unmarried female, aged more than 54 years, resident of the city for less than one year, afflicted with an unknown disease, and admitted to Touro during January or February, 1855 .

$* * *, * *$, and $*$ denote significance at the $1 \%, 5 \%$ and $10 \%$ levels, respectively. 
Table 4

Decomposition of the Difference in Mortality Rates between Whites and Slaves

Aggregate and Sub-Aggregate Effects

\begin{tabular}{|c|c|c|c|c|c|}
\hline & \multicolumn{2}{|c|}{ Characteristics Effect } & \multicolumn{2}{|c|}{ Coefficients Effect } & \multirow{2}{*}{$\begin{array}{c}\text { Combined } \\
\text { Effect }\end{array}$} \\
\hline & Est. & Share & Est. & Share & \\
\hline Aggregate Effect & $\begin{array}{c}0.0875^{* * * *} \\
(0.0189)\end{array}$ & 50.93 & $\begin{array}{c}0.0843 * * * \\
(0.0225)\end{array}$ & 49.07 & 100.00 \\
\hline \multicolumn{6}{|l|}{ Sub-Aggregate Effects } \\
\hline Gender & $\begin{array}{c}-0.0024 * \\
(0.0015)\end{array}$ & -1.41 & $\begin{array}{c}0.0123 \\
(0.0139)\end{array}$ & 7.14 & 5.73 \\
\hline Marital status & $\begin{array}{l}-0.0008 \\
(0.0023)\end{array}$ & -0.48 & $\begin{array}{l}-0.0123 \\
(0.0121)\end{array}$ & -7.15 & -7.63 \\
\hline Age of patient & $\begin{array}{l}-0.0048 * \\
(0.0029)\end{array}$ & -2.82 & $\begin{array}{l}-0.0267 \\
(0.0262)\end{array}$ & -15.56 & -18.38 \\
\hline Residence in New Orleans & $\begin{array}{l}-0.0242 \\
(0.0154)\end{array}$ & -14.08 & $\begin{array}{l}-0.0027 \\
(0.0106)\end{array}$ & -1.60 & -15.68 \\
\hline Month of admission & $\begin{array}{c}0.0688 * * * \\
(0.0118)\end{array}$ & 40.07 & $\begin{array}{l}-0.0040 \\
(0.0080)\end{array}$ & -2.33 & 37.74 \\
\hline Malady & $\begin{array}{c}0.0458 * * * \\
(0.0142)\end{array}$ & 26.69 & $\begin{array}{c}0.0096 \\
(0.0097)\end{array}$ & 5.58 & 32.27 \\
\hline Year of admission & $\begin{array}{c}0.0051 \\
(0.0134)\end{array}$ & 2.95 & $\begin{array}{l}-0.0004 \\
(0.0154)\end{array}$ & -0.24 & 2.71 \\
\hline Intercept & 0 & 0 & $\begin{array}{c}0.1086 * * * \\
(0.0382)\end{array}$ & 63.23 & 63.23 \\
\hline
\end{tabular}

Source: Estimates derived from Tables 1 and 3.

Notes: The share is calculated as a proportion to the mortality rate gap of $17.16 \%$ between whites and slaves. Standard errors are reported in parentheses. $* * *, * *$, and $*$ denote significance at the $1 \%, 5 \%$ and $10 \%$ levels, respectively. 


\section{Works Cited}

Abowd, John M. and Mark R. Killingsworth., 1984. "Do Minority/White Unemployment Differences Really Exist?” Journal of Business and Economic Statistics 2: 64-72.

Bankole, Katherine Olukemi, 2001. "African Females and the Antebellum Hospital Experience.” Journal of Black Studies 31: 517-38. , 1998. Slavery and Medicine: Enslavement and Medicinal Practices in Antebellum Louisiana. New York: Garland Publishing, Inc., 1998.

Burnett, Walter M., 1979. Touro Infirmary. Baton Rouge: Moran Publishing Corporation.

Cohen, 1855. Cohen's New Orleans Directory for 1855. New Orleans: Office of the Picayune.

Deyle, Steven, 2005. Carry Me Back: The Domestic Slave Trade in American Life. New York: Oxford University Press.

Fairlie, Robert W., 2005. "An Extension of the Blinder-Oaxaca Decomposition Technique to Logit and Probit Models.” Journal of Economic and Social Measurement 30: 305316.

Fogel, Robert William, 1989. Without Consent or Contract: the Rise and Fall of American Slavery. New York: Norton.

Fogel, Robert William and Stanley L. Engerman, 1974. Time on the Cross. Boston: Little, Brown.

Genovese, Eugene D., 1976. Roll, Jordan, Roll: the World the Slaves Made. New York: Vintage Books.

Goldin, Claudia, and Robert A. Margo, 1989. "The Poor at Birth: Birth Weights and Infant Mortality at Philadelphia's Almshouse Hospital, 1848-1873." Explorations in Economic History 26: 360-379.

Goodson, Martia Graham, 2003. "Enslaved Africans and Doctors in South Carolina." Journal of the National Medical Association 95: 225-33.

Ham, John C., Jan Svejnar and Katherine Terrell, 1998. "Unemployment and the Social Safety Net During Transitions to a Market Economy: Evidence from the Czech and Slovak Republics.” American Economic Review 88: 1117-1142. 
Kiple, Kenneth F., and Virginia Himmelsteib King, 1981. Another Dimension to the Black Diaspora Diet, Disease, and Racism. Cambridge: Cambridge University Press.

Kotlikoff, Laurence J., 1992. "Quantitative Description of the New Orleans Slave Market, 1804 to 1862," in Robert W. Fogel and Stanley L. Engerman, editors, Without Consent or Contract: Technical Papers on Slavery. New York: W. W. Norton.

Lander, Kevin and Jonathan B. Pritchett, 2008. "When to Care: The Economic Rationale of Slavery Health Care Provision.” Working Paper. Tulane University. pp. 1-36.

Louisiana, 1806. Acts Passed at the First Session of the First Legislature of the Territory of Orleans. New Orleans: Bradford \& Anderson.

Matas, Rudolph, 1962. The Rudolph Matas History of Medicine in Louisiana. J. Duffy (ed.) Baton Rouge: Rudolph Matas Trust Fund by Louisiana State University Press.

Meeker, Edward, 1976. "Mortality Trends of Southern Blacks, 1850 - 1910: Some Preliminary findings." Explorations in Economic History 13: 13-42.

New Orleans Advertiser, various dates.

New Orleans Bee, various years.

Oaxaca, Ronald, 1973. "Male-Female Wage Differentials in Urban Labor Markets." International Economic Review 14: 693-709.

Oaxaca, Ronald and Michael R. Ransom, 1999. "Identification in Detailed Wage Decompositions." Review of Economics and Statistics 81: 154-157.

Phillips, Ulrich Bonnel, 1918. American Negro Slavery. New York: D. Appleton and Company. , 1929. Life and Labor in the Old South. Boston: Little, Brown and Company.

Postell, William D., 1951. The Health of Slaves on Southern Plantations. Baton Rouge: Louisiana State University Press.

Richardson, T.G., 1861. "Report of Stone's Infirmary, for the year ending August 31 1860." New Orleans Medical and Surgical Journal 18:201-224.

Rosenberg, Charles E., 1987. The Care of Strangers: The rise of America's hospital system. New York: Basic Books.

Savitt, Todd L., 1978. Medicine and Slavery: The Diseases and Health Care of Blacks in Antebellum Virginia. Urbana, IL: University of Illinois Press. 
Shryock, Richard H., 1930. "Medical Practice in the Old South." South Atlantic Quarterly 29: $160-78$.

Stampp, Kenneth M., 1956. The Peculiar Institution. New York: Vintage Books.

Steckel, Richard H., 1986. "A Dreadful Childhood: The Excess Mortality of American Slaves." Social Science History 10: 427-465.

Tunal1, İnsan and Jonathan B. Pritchett, 1997. "Cox Regression with Alternative Concepts of Waiting Time: The New Orleans Yellow Fever Epidemic of 1853." Journal of Applied Econometrics 12: 1-25.

U.S. Bureau of the Census, 1864. Population of the United States in 1860. Washington: GPO.

Wade, Richard C., 1964. Slavery in the Cities: The South 1820 - 1860. New York: Oxford.

Warren, Christian, 1997. "Northern Chills, Southern Fevers: Race-Specific Mortality in American Cities, 1730-1900." Journal of Southern History 63: 23-56.

Washington, Harriet A., 2006. Medical Apartheid the Dark History of Medical Experimentation on Black Americans From Colonial Times to the Present. New York: Doubleday.

World Health Organization, 2007. "Diseases covered by NTD Department." April 28, 2008. $<$ http://www.who.int/neglected_diseases/diseases/en/>.

Yun, Myeong-Su, 2004. "Decomposition Differences in the First Moment." Economics Letters 82: 273-278.

Yun, Myeong-Su, 2005a. "Hypothesis Tests when Decomposing Differences in the First Moment." Journal of Economic and Social Measurement 30: 295-304.

Yun, Myeong-Su, 2005b. "A Simple Solution to the Identification Problem in Detailed Wage Decomposition." Economic Inquiry 43: 766-772. 
Appendix:

Table 5

Probit Regression Results, Touro Infirmary, 1855-1860

Combined Sample, Charity and Paying Patients

\begin{tabular}{|c|c|c|c|c|}
\hline & Coefficient & Standard error & Mean & Standard error \\
\hline Intercept & $-1.367 * * *$ & 0.497 & 1 & N.A. \\
\hline \multicolumn{5}{|l|}{ Gender and marital status } \\
\hline Male & $-0.483 * * *$ & 0.147 & 0.795 & 0.404 \\
\hline Married & -0.018 & 0.155 & 0.230 & 0.421 \\
\hline \multicolumn{5}{|l|}{ Age of patient } \\
\hline Aged 0 to 14 years & -0.680 & 0.534 & 0.033 & 0.178 \\
\hline Aged 15 to 24 years & -0.311 & 0.384 & 0.364 & 0.481 \\
\hline Aged 25 to 34 years & -0.207 & 0.377 & 0.369 & 0.483 \\
\hline Aged 35 to 44 years & 0.033 & 0.386 & 0.151 & 0.358 \\
\hline Aged 45 to 54 years & 0.182 & 0.435 & 0.053 & 0.224 \\
\hline \multicolumn{5}{|l|}{ Residence in New Orleans } \\
\hline $\begin{array}{l}\text { New Orleans resident, } 1 \text { to } 4 \\
\text { years }\end{array}$ & -0.168 & 0.189 & 0.152 & 0.359 \\
\hline $\begin{array}{l}\text { New Orleans resident, } 5 \text { years } \\
\text { or more }\end{array}$ & -0.006 & 0.167 & 0.259 & 0.438 \\
\hline \multicolumn{5}{|l|}{ Month of admission } \\
\hline Admitted in March or April & -0.025 & 0.302 & 0.180 & 0.385 \\
\hline Admitted in May or June & $0.638^{* *}$ & 0.297 & 0.149 & 0.356 \\
\hline Admitted in July or August & $0.986 * * *$ & 0.273 & 0.225 & 0.418 \\
\hline $\begin{array}{l}\text { Admitted in September or } \\
\text { October }\end{array}$ & $0.730 * * *$ & 0.280 & 0.207 & 0.406 \\
\hline $\begin{array}{l}\text { Admitted in November or } \\
\text { December }\end{array}$ & $0.859 * * *$ & 0.322 & 0.083 & 0.277 \\
\hline \multicolumn{5}{|l|}{ Malady } \\
\hline Afflicted with a tropical disease & $0.534 * *$ & 0.208 & 0.443 & 0.497 \\
\hline $\begin{array}{l}\text { Afflicted with a non-tropical } \\
\text { disease }\end{array}$ & 0.037 & 0.215 & 0.391 & 0.488 \\
\hline \multicolumn{5}{|l|}{ Year of Admission } \\
\hline Admitted in 1856 & -0.169 & 0.202 & 0.243 & 0.429 \\
\hline Admitted in 1857 & 0.108 & 0.186 & 0.285 & 0.452 \\
\hline Admitted in 1858 & $0.546 * * *$ & 0.189 & 0.120 & 0.326 \\
\hline Admitted in 1860 & $0.632^{*}$ & 0.340 & 0.071 & 0.257 \\
\hline
\end{tabular}


Table 5

Probit Regression Results, Touro Infirmary, 1855-1860

Combined Sample, Charity and Paying Patients

Coefficient Standard error

Mean

Standard error

Status of patient

$\begin{array}{lcccc}\text { Slave } & -0.510^{* * *} & 0.161 & 0.521 & 0.500 \\ \text { Charity } & -0.018 & 0.198 & 0.104 & 0.305\end{array}$

Sample size

888

Log-likelihood

148.018

Source: Touro Hospital Admission Records.

Note: N.M. indicates that the statistic is not meaningful. Tropical diseases include yellow fever, diarrhea and dysentery, malaria, typhoid, tuberculosis, unclassified fevers, and cholera. The omitted category refers to an unmarried white female, aged more than 54 years, resident of the city for less than one year, afflicted with an unknown disease, and admitted to Touro during January or February, 1855.

$* * *, * *$, and $*$ denote significance at the $1 \%, 5 \%$ and $10 \%$ levels, respectively. 
Table 6

Decomposition of the Differences in Mortality Rates between Freemen and Slaves

\begin{tabular}{|c|c|c|c|c|}
\hline & \multicolumn{2}{|c|}{ Characteristics Effect } & \multicolumn{2}{|c|}{ Coefficients Effect } \\
\hline & Estimate & Share & Estimate & Share \\
\hline Aggregate effect & $\begin{array}{r}0.0875 * * * \\
(0.0189)\end{array}$ & 50.93 & $\begin{array}{r}0.0843 * * * \\
(0.0225)\end{array}$ & 49.07 \\
\hline Intercept & 0 & 0 & $\begin{array}{r}0.1086^{* * * *} \\
(0.0382)\end{array}$ & 63.23 \\
\hline Gender & $\begin{array}{c}-0.0024^{*} \\
(0.0015)\end{array}$ & -1.41 & $\begin{array}{r}0.0123 \\
(0.0139)\end{array}$ & 7.14 \\
\hline Female & $\begin{array}{c}-0.0012^{*} \\
(0.0007)\end{array}$ & -0.70 & $\begin{array}{r}-0.0053 \\
(0.0060)\end{array}$ & -3.07 \\
\hline Male & $\begin{array}{c}-0.0012 * \\
(0.0007)\end{array}$ & -0.70 & $\begin{array}{r}0.0175 \\
(0.0199)\end{array}$ & 10.21 \\
\hline Marital status & $\begin{array}{r}-0.0008 \\
(0.0023)\end{array}$ & -0.48 & $\begin{array}{r}-0.0123 \\
(0.0121)\end{array}$ & -7.15 \\
\hline Single & $\begin{array}{r}-0.0004 \\
(0.0011)\end{array}$ & -0.24 & $\begin{array}{r}-0.0206 \\
(0.0202)\end{array}$ & -12.01 \\
\hline Married & $\begin{array}{r}-0.0004 \\
(0.0011)\end{array}$ & -0.24 & $\begin{array}{r}0.0084 \\
(0.0082)\end{array}$ & 4.86 \\
\hline Age of patient & $\begin{array}{c}-0.0048 * \\
(0.0029)\end{array}$ & -2.82 & $\begin{array}{r}-0.0267 \\
(0.0262)\end{array}$ & -15.56 \\
\hline Aged less than 15 years & $\begin{array}{r}0.0001 \\
(0.0004)\end{array}$ & 0.03 & $\begin{array}{r}0.0013 \\
(0.0041)\end{array}$ & 0.74 \\
\hline Aged 15 to 24 years & $\begin{array}{r}-0.0041 \\
(0.0024)\end{array}$ & -2.41 & $\begin{array}{r}-0.0083 \\
(0.0144)\end{array}$ & -4.85 \\
\hline Aged 25 to 34 years & $\begin{array}{r}0.0008 \\
(0.0005)\end{array}$ & 0.48 & $\begin{array}{r}-0.0152 \\
(0.0180)\end{array}$ & -8.86 \\
\hline Aged 35 to 44 years & $\begin{array}{r}-0.0004 \\
(0.0014)\end{array}$ & -0.26 & $\begin{array}{r}-0.0045 \\
(0.0095)\end{array}$ & -2.61 \\
\hline Aged 45 to 54 years & $\begin{array}{r}-0.0001 \\
(0.0006)\end{array}$ & -0.07 & $\begin{array}{r}-0.0061 \\
(0.0055)\end{array}$ & -3.56 \\
\hline Aged 55 years or more & $\begin{array}{r}-0.0010 \\
(0.0009)\end{array}$ & -0.59 & $\begin{array}{r}0.0062 \\
(0.0048)\end{array}$ & 3.58 \\
\hline Residence in New Orleans & $\begin{array}{r}-0.0242 \\
(0.0154)\end{array}$ & -14.08 & $\begin{array}{r}-0.0027 \\
(0.0106)\end{array}$ & -1.60 \\
\hline New Orleans resident, less than 1 year & $\begin{array}{r}-0.0106 \\
(0.0072)\end{array}$ & -6.20 & $\begin{array}{r}-0.0269^{*} \\
(0.0146)\end{array}$ & -15.67 \\
\hline New Orleans resident, 1 to 4 years & $\begin{array}{c}0.00002 \\
(0.0001)\end{array}$ & 0.01 & $\begin{array}{r}0.0039 \\
(0.0068)\end{array}$ & 2.27 \\
\hline New Orleans resident, 5 years or more & $\begin{array}{r}-0.0136 \\
(0.0103)\end{array}$ & -7.90 & $\begin{array}{r}0.0203 \\
(0.0180)\end{array}$ & 11.80 \\
\hline Month of admission & $\begin{array}{r}0.0688 * * * \\
(0.0118)\end{array}$ & 40.07 & $\begin{array}{r}-0.0040 \\
(0.0080)\end{array}$ & -2.33 \\
\hline Admitted in January or February & $\begin{array}{r}0.0011 \\
(0.0007)\end{array}$ & 0.62 & $\begin{array}{r}-0.0030 \\
(0.0102)\end{array}$ & -1.74 \\
\hline
\end{tabular}


Admitted in March or April

Admitted in May or June

Admitted in July or August

Admitted in September or October

Admitted in November or December

Reason of admission

Afflicted with an unknown disease

Afflicted with a tropical disease

Afflicted with a non-tropical disease

Year of admission

Admitted in 1855

Admitted in 1856

Admitted in 1857

Admitted in 1858

Admitted in 1859

Admitted in 1860

\begin{tabular}{|c|c|c|c|}
\hline $0.0364 * * *$ & 21.19 & -0.0324 & -18.84 \\
\hline$(0.0081)$ & & $(0.0287)$ & \\
\hline-0.0034 & -2.00 & 0.0008 & 0.48 \\
\hline$(0.0052)$ & & $(0.0110)$ & \\
\hline $0.0156^{* * *}$ & 9.06 & 0.0116 & 6.78 \\
\hline$(0.0026)$ & & $(0.0106)$ & \\
\hline $0.0204 * * *$ & 11.86 & $0.0274 *$ & 15.98 \\
\hline$(0.0065)$ & & $(0.0143)$ & \\
\hline-0.0011 & -0.67 & -0.0086 & -4.98 \\
\hline$(0.0017)$ & & $(0.0078)$ & \\
\hline $0.0458 * * *$ & 26.69 & 0.0096 & 5.58 \\
\hline$(0.0142)$ & & $(0.0097)$ & \\
\hline $0.0062 * *$ & 3.60 & $-0.0198 *$ & -11.52 \\
\hline$(0.0027)$ & & $(0.0118)$ & \\
\hline $0.0347 * * *$ & 20.23 & $0.0349 *$ & 20.30 \\
\hline (0.0098) & & $(0.0182)$ & \\
\hline 0.0049 & 2.86 & -0.0055 & -3.20 \\
\hline$(0.0079)$ & & $(0.0175)$ & \\
\hline 0.0051 & 2.95 & -0.0004 & -0.24 \\
\hline$(0.0134)$ & & $(0.0154)$ & \\
\hline-0.0024 & -1.41 & 0.0017 & 0.97 \\
\hline$(0.0054)$ & & $(0.0048)$ & \\
\hline 0.0076 & 4.431 & -0.0131 & -7.64 \\
\hline$(0.0051)$ & & $(0.0154)$ & \\
\hline-0.0098 & -5.69 & 0.0137 & 7.97 \\
\hline$(0.0087)$ & & $(0.0160)$ & \\
\hline 0.0085 & 4.92 & -0.0103 & -5.99 \\
\hline$(0.0065)$ & & $(0.0093)$ & \\
\hline 0.0042 & 2.44 & 0.0086 & 4.98 \\
\hline$(0.0027)$ & & $(0.0112)$ & \\
\hline-0.0030 & -1.74 & -0.0009 & -0.53 \\
\hline$(0.0028)$ & & $(0.0072)$ & \\
\hline
\end{tabular}

Source: Estimates derived from Tables 1 and 3.

Notes: The share is calculated as a proportion to the mortality rage gap of $17.16 \%$ between whites and slaves. Standard errors are reported in parentheses. ***, **, and * denote significance at the $1 \%, 5 \%$ and $10 \%$ levels, respectively. 